\title{
Growth inhibitory action of saccharin and cyclamate on rats receiving a poor rice diet*
}

\author{
By M. I. SABRI, $\uparrow$ S. K. SHARMA AND C. R. KRISHNA MURTI \\ Central Drug Research Institute, Lucknow, India
}

(Received ro September 1968-Accepted 23 Fanuary 1969)

\begin{abstract}
I. The effect of saccharin and cyclamate on growth of young rats fed on a poor rice diet or a balanced diet was investigated.

2. Saccharin and cyclamate retarded the growth of rats on the multi-deficient diet but not of those on the well-balanced diet during an 8-week feeding period.

3. The sweeteners did not produce any macroscopic or microscopic changes in the liver, kidneys, intestines, spleen or lungs of the animals receiving the poor rice diet other than the changes resulting from the nutritional deficiency of the diet.

4. The sweeteners did not inhibit the liver xanthine oxidase activity of rats receiving the poor rice diet to an extent greater than the inhibition brought about by the deficiency of protein in the diet.

5. When given by intubation to healthy rats, the sweeteners inhibited the induction of liver tryptophan oxygenase; given in vitro, they inhibited the succinate dehydrogenase activity of rat liver mitochondria.
\end{abstract}

Acute shortage of cane sugar and its increasing cost have forced many in India to use saccharin or cyclamate in their beverages and confections. The available information on the toxicity of these agents does not permit an accurate assessment of the possible harmful effects of the unrestricted consumption of artificial sweeteners by an already undernourished population. As a small beginning towards the acquisition of relevant information on the subject, the present study was undertaken to see whether saccharin or cyclamate affected the growth of rats raised on a multi-deficient diet simulating the composition and nutritional value of the average diet of a rice eater in India.

\section{MATERIALS AND METHODS}

Animals. Albino rats from the colony of this Institute were used.

Diets. The multi-deficient rice diet and the balanced synthetic diet were prepared as described in earlier reports (Krishna Murti \& Subrahmanyan, I949; Sharma \& Krishna Murti, 1966).

Feeding experiments. Male and female weanlings (23-45 $\mathrm{g}$ in weight) were divided in equal numbers into two groups of thirty. Three subgroups of ten each were formed out of these two major divisions. The sweeteners were added to make up $0.0 \mathrm{\%} \%$ of the dry weight of the diet during the first 4 weeks and $\mathrm{I} \cdot 0 \%$ of the dry weight during the rest of the 4 -week period. The animals were housed in individual cages; they were fed $a d l i b$. and weighed at weekly intervals. Food left uneaten was weighed. At the

* Communication N. I250 from the Central Drug Research Institute, Lucknow, India.

$\uparrow$ Present address: Department of Physiology, Indiana University Medical Centre, Indianapolis, Indiana 46207 , USA. 
end of the experiment the animals were decapitated and their tissues were excised and collected in chilled normal saline. Portions of the tissues were fixed for pathological examination and the rest used for enzymic studies.

Induction of tryptophan oxygenase. Twenty-four adult rats (I60-175 g in weight) were starved overnight and fed L-tryptophan (I $\mathrm{mg} / \mathrm{g}$ body-weight) either intraperitoneally or by intubation, one group receiving in addition by the same mode of administration the sweetener ( $10 \mathrm{mg} / \mathrm{g}$ body-weight). 'Three rats in the group receiving only Ltryptophan, the inducer, served as controls for determining the basal level of enzymes before and after induction. All the animals received a second dose of L-tryptophan $4 \mathrm{~h}$ after the beginning of the experiment. The animals were killed $8 \mathrm{~h}$ after the first dose of L-tryptophan.

Action on liver mitochondria. Fresh rat liver mitochondria prepared according to Schneider \& Hogeboom ( $195^{\circ}$ ) were dispersed at a concentration of $30 \mathrm{mg}$ protein $/ \mathrm{ml}$ in a medium containing $250 \mathrm{~mm}$-sucrose and $66 \mathrm{~mm}$-phosphate buffer $(\mathrm{pH} 7 \cdot 2)$ and incubated with the required amount of the sweetener for 30 min at $37^{\circ}$. The suspensions were used as such for the assay of succinate dehydrogenase.

Enzyme assays. The methods were: for succinate dehydrogenase (succinate: (acceptor) oxido-reductase, $E C$ I.3.99.I) that of Srikantan \& Krishna Murti (1955), for xanthine oxidase (xanthine:oxygen oxido-reductase, $E C$ I.2.3.2) that of Litwack, Bothwell, Williams \& Elvehjem (I953), and for tryptophan oxygenase (tryptophan oxygen oxido-reductase, $E C$ I.I3.I.I2) that of Knox (1955). Protein was determined colorimetrically according to Lowry, Rosebrough, Farr \& Randall (I95I) with bovine plasma albumin as standard.

\section{RESUITS}

Growth. The results summarized in Table I show that both saccharin and cyclamate depressed the growth rate of the animals throughout the period during which they consumed the poor rice diet, the differences in weight gain between the groups receiving and those not receiving the sweeteners being statistically significant $(P<$ 0.01 ). In contrast, the sweeteners stimulated the growth rate of animals raised on the synthetic diet, the differences in weight gain between the groups receiving and not receiving the sweeteners becoming statistically significant towards the $7^{\text {th }}$ and 8 th weeks $(P<0.05)$. There was no significant difference in the amount of food consumed by the animals on the poor rice diet whether they received the sweeteners or not. However, the food consumed by the animals on the synthetic diet was relatively more in the groups receiving the sweeteners than in the control group.

Histopathological examination. Apart from patchy congestive haemorrhage in the lungs and in the viscera (presumably due to the method of killing the animals before autopsy) and some granulomatous lesions in the liver and spleen in some samples, no pathological lesions were seen in sections of the control or experimental animals. The cells of the renal epithelium, liver, stomach and intestines showed no evidence of drug toxicity such as oedema, fatty changes or necrosis.

Liver xanthine oxidase. The effect of the generalized malnutrition to which the animals on the poor rice diet were exposed was reflected in a lowered liver xanthine 
oxidase activity. However, the differences in enzymic activity between the groups receiving and those not receiving the sweeteners were not significant. The liver weights expressed as a percentage of body-weight showed some variation in the rats consuming the rice diet containing cyclamate as compared with the group not getting the sweetener. The differences in liver weight between the two groups, though significant, were

Table I. Effect of saccharin and cyclamate on the growth of rats raised on a poor rice diet and on a well-balanced diet

\begin{tabular}{|c|c|c|c|c|c|}
\hline \multirow[b]{2}{*}{ Days on diet } & \multicolumn{5}{|c|}{ Weight gain (g) on poor rice diet } \\
\hline & Alone & (control) & With saccharin & With & cyclamate \\
\hline 7 & $7 \cdot 0)$ & \multirow{8}{*}{$x \cdot 7(10)$} & $I \cdot O)$ & $I \cdot I)$ & \multirow{8}{*}{$2 \cdot 4(10)$} \\
\hline I4 & $16 \cdot 3$ & & $9 * 7$ & $8 \cdot 3$ & \\
\hline $2 I$ & $22 \cdot 6$ & & $14 \cdot 6$ & I I 7 & \\
\hline 28 & $27 \cdot 3$ & & $19 \cdot 4$ & $15 \% 4$ & \\
\hline 35 & $33 \cdot 9$ & & $22 * 3$ & I $7 \cdot 3$ & \\
\hline 42 & $38 \cdot 5$ & & $24 \cdot 2$ & 20.9 & \\
\hline 49 & $42 \cdot 6$ & & $28 \cdot 9$ & $22 \cdot 6$ & \\
\hline 56 & $44 \cdot 7$ & & $30 \cdot 1$ & $22 \cdot 3)$ & \\
\hline \multicolumn{6}{|c|}{ All significant at $P<0.01$} \\
\hline & \multicolumn{5}{|c|}{ Weight gain (g) on well-balanced diet } \\
\hline & Alone & (control) & With saccharin & With & cyclamate \\
\hline 7 & $16 \cdot 7)$ & \multirow{8}{*}{$3 \cdot 7(7)$} & \multirow{8}{*}{$3 \cdot 3(9)$} & $19 * 4)$ & \multirow{8}{*}{$\mathrm{I} \cdot 8(\mathrm{10})$} \\
\hline I 4 & $32 \cdot 7$ & & & $40 \cdot 3$ & \\
\hline $2 \mathrm{I}$ & $37^{\circ} 4$ & & & $49 \cdot 6$ & \\
\hline 28 & $47 \cdot 9$ & & & $5^{8 \cdot 9}$ & \\
\hline 35 & 54.7 & & & $64 \cdot 0$ & \\
\hline 42 & $64 \cdot I$ & & & $76 \cdot 7$ & \\
\hline 49 & $7 \mathrm{I} \cdot \mathrm{I}$ & & & 84.6 & \\
\hline 56 & $(73.9)$ & & & $83 \cdot 6)$ & \\
\hline
\end{tabular}

Values of deviation from control significant at $P<0.05$ for the last 4 weeks

Values given are mean weight gain during the period and the single figure the mean of the standard deviations of all the periods studied. The figures in parentheses are the number of animals in each group.

Values of $P$ were derived from an $F$ test of the variability between the three treatments.

Table 2. Effect of adding saccharin and cyclamate to the diet on liver weight and liver xanthine oxidase activity of rats raised on a poor rice diet and on a well-balanced diet

$\begin{array}{ccc}\text { No. of } & \text { Liver weight } & \text { Xanthine oxidase } \\ \text { animals } & \text { (g/roog body-wt) } & \text { (units/g liver) }\end{array}$

\begin{tabular}{llll} 
None & \multicolumn{2}{l}{ Well-balanced diet } \\
Saccharin added & 7 & $2.92(0.01)$ & $I \cdot 17(0.25)$ \\
Cyclamate added & 9 & $2.68(0.33)$ & $1 \cdot 39(0.46)$ \\
& 9 & $2.49(0.27)$ & $1 \cdot 44(0.38)$ \\
None & \multicolumn{2}{c}{ Poor rice diet } \\
Saccharin added & 8 & $3.50(0.13)$ & $0.7(0.26)$ \\
Cyclamate added & 7 & $3.70(0.28)$ & $0.7(0.49)$ \\
& 6 & $4.30(0.19)$ & $0.7(0.28)$
\end{tabular}

The numbers in parentheses are the standard errors.

One unit of xanthine oxidase is the amount of enzyme required to oxidize $1 \mu$ mole xanthine in $60 \mathrm{~min}$ at $37^{\circ}$. 
not correlated with any histological changes. As expected, the liver weight of rats on the poor rice diet was higher than that of animals on the balanced diet. The relevant results are summarized in Table 2.

Mitochondrial succinate dehydrogenase. Results given in Table 3 show that both saccharin and cyclamate inhibited the enzyme.

Table 3. Effect of incubation with saccharin or cyclamate on succinate dehydrogenase activity of rat liver mitochondria

\begin{tabular}{|c|c|}
\hline Sweetener added* & $\begin{array}{l}\text { Formazan pro- } \\
\text { duced (m } \mu \text { moles/ } \\
\text { mg protein per } \mathrm{h})\end{array}$ \\
\hline $\begin{array}{l}\text { None } \\
\text { Saccharin: 10 } \mu \text { moles }\end{array}$ & $\begin{array}{l}90 \cdot 0 \\
60 \cdot 0\end{array}$ \\
\hline $20 \mu$ moles & $49^{\circ} \circ$ \\
\hline $30 \mu$ moles & $46 \cdot 0$ \\
\hline $40 \mu$ moles & $47^{\circ} \circ$ \\
\hline $50 \mu$ moles & $47 \cdot 0$ \\
\hline Cyclamate: $50 \mu$ moles & $5 I \cdot 0$ \\
\hline
\end{tabular}

* Added to $1 \mathrm{ml}$ mitochondria and incubated for $30 \mathrm{~min}$ before enzyme assay.

Table 4. Effect of saccharin and cyclamate on induction of tryptophan oxygenase in rat's liver

\begin{tabular}{|c|c|c|}
\hline \multirow[b]{2}{*}{ Treatment } & \multicolumn{2}{|c|}{ Kyneurenine produced $(\mathrm{m} \mu$ moles $/ g$ liver per $\mathrm{h})$} \\
\hline & $A *$ & $\mathrm{~B}+$ \\
\hline $\begin{array}{l}\text { None (control) } \\
\text { Tryptophan, no sweetener } \\
\text { Tryptophan and saccharin } \\
\text { Tryptophan and cyclamate }\end{array}$ & $\begin{array}{c}890(630-1 \text { I } 50) \\
5800(4240-6340) \\
4720(4340-5100) \\
4560(4160-4960)\end{array}$ & $\begin{array}{c}300(250-350) \\
6520(5780-7200) \\
6200(5340-7060) \\
4720(4170-5270)\end{array}$ \\
\hline
\end{tabular}

Three rats used in each group. The wide fluctuation in the basal activity of the enzyme (control values) before treatment did not warrant a detailed analysis with the three sets of values.

* Inducer and the sweetener administered intraperitoneally.

+ Inducer and the sweetener given by intubation.

The figures in parentheses are the range of values.

Induction of L-tryptophan oxygenase. Results of induction experiments with groups of three rats are given in Table 4. The basal level of the enzyme and the values after induction in each treatment showed wide fluctuation. A tentative inference drawn from the study is that the induction pattern is not altered significantly when the sweetener is administered along'with the inducer by the intraperitoneal route, although there is a tendency associated with the sweeteners, particularly, cyclamate, to lower the level of the induced enzyme when they were administered along with the inducer by intubation.

\section{DISCUSSION}

The results of the present preliminary study reveal a growth-retarding action of both saccharin and cyclamate on young rats subsisting on a multi-deficient rice diet but not in those given a well-balanced diet. The inhibited growth of the animals on the rice diet as compared with that of the animals on the synthetic diet was reflected 
in the low liver xanthine oxidase activity of the former group in conformity with the well-known effect of low-protein diets to depress the level of liver xanthine oxidase. However, between the animals not receiving and those receiving the sweeteners there was no difference in enzyme activity. There was some indication that the liver weight of animals on the rice diet which also received cyclamate was greater at the time they were examined. This greater liver weight was nota result of a changed histopathological state since no untoward cytological changes were noted in the tissues of animals ingesting cyclamate.

The induction of microsomal enzymes leading to structural changes in the endoplasmic reticulum is now recognized as an important regulatory mechanism, and any effects of dietary additions on this mechanism must be examined carefully. The inhibition of tryptophan oxygenase induction by cyclamate, as revealed in the present study, needs to be investigated further, so as to determine whether cyclamate affects primary homoeostatic mechanism. Induction of microsomal enzymes is nature's device for disposing of drugs and agents foreign to the metabolism of the animal. The inhibitory action of cyclamate on tryptophan oxygenase assumes therefore an added significance. The inhibitory action of the sweeteners on mitochondrial succinate dehydrogenase in vitro may also have related effects in vivo perhaps on oxidative phosphorylation.

The world-wide use of saccharin and cyclamate in soft drinks has shown a steady upward trend in recent years. While this development may not present health hazards to those consuming a nutritionally adequate diet, it would be wise to be wary of the generally held view that artificial sweeteners are completely free from side-effects. Salmon \& Roe (1956) have reported an incriminating effect of saccharin in experimental skin tumour of the mouse, and Nees \& Derse (I967) attributed to calcium cyclamate an interfering action in adrenal function, leading to growth retardation of the rat. These reports and the present study indicate that the safety of artificial sweeteners needs further examination.

The authors' thanks are due to Mr P. A. George of the Biometrics Department for the statistical analysis, to the Director, Sarabhai Research and Development Laboratory, Baroda, for the gift of saccharin and cyclamate used in this study and to Col. T. K. Narayanan, Pathologist, Command Laboratory, Lucknow, for the histopathological report on the tissues.

\section{REFERENCES}

Knox, W. E. (1955). In Methods in Enzymology, vol. II, p. 242 [S. P. Colowick and N. O. Kaplan, editors.] New York: Academic Press Inc.

Krishna Murti, C. R. \& Subrahmanyan, V. (1949). Indian F. med. Res. 37, 33.

Litwack, G., Bothwell, J. W., Williams, J. N. Jr \& Elvehjem, C. A. (1953). Ұ. biol. Chem. 200, 303.

Lowry, O. H., Rosebrough, N. J., Farr, A. L. \& Randall, R. J. (r95 r). F. biol. Chem. 193, 265.

Nees, P. O. \& Derse, P. H. (1967). Nature, Lond. 213, Ir91.

Salmon, M. H. \& Roe, F. J. C. (1956). Br. F. Cancer 1o, 363.

Schneider, W. C. \& Hogeboom, G. H. (1950). F. biol. Chem. 183, I23.

Sharma, S. K. \& Krishna Murti, C. R. (1966). Biochem. Pharmac. 15, 2028.

Srikantan, T. N. \& Krishna Murti, C. R. (1955). F. scient. ind. Res. I4C, 206.

\section{Printed in Great Britain}

